\title{
Effect of Heat Treatment on Shore-D Hardness of Some Wood Species
}

\author{
Bruno Esteves, ${ }^{\mathrm{a}}$ Sırrı Sahin, ${ }^{\mathrm{b}}$ Ümit Ayata, ${ }^{\mathrm{c}, *}$ Idalina Domingos, ${ }^{\mathrm{a}}$ José Ferreira, ${ }^{\mathrm{a}}$ and \\ Levent Gürleyen ${ }^{\text {d }}$
}

\begin{abstract}
Hardness is an important wood property for several applications. Typically, it is necessary to use traditional methods, such as a universal test machine, to determine a wood's hardness value. This work reports the hardness of some wood species before and after heat treatment (ThermoWood method) using the Shore-D hardness method. The Shore$D$ hardness value of untreated wood ranged between 35.3 for Limba wood and 77.2 for Santos wood. With heat treatment, hardness decreased, and the decrease was greater for samples that underwent harsher treatment $\left(2 \mathrm{~h}\right.$ at $\left.212^{\circ} \mathrm{C}\right)$. The decrease of hardness was highest for Sipo wood $(14 \%)$ and the lowest for Afrormosia wood (2.5\%). Analysis of variance tests showed that there was a significant difference between wood species, heat treatment, and the interaction between both variables at the chosen level of significance $(P \leq 0.05)$. Results showed that Shore-D hardness could be used to measure hardness directly in a production line or in small wood companies without using a universal test machine.
\end{abstract}

Keywords: Shore-D hardness; Exotic wood species; Heat treatment; ThermoWood

Contact information: a: Polytechnic Institute of Viseu and Research Center for Natural Resources, Environment and Society (CERNAS) Viseu, Portugal; b: Department of Agricultural Buildings and Irrigation, Agriculture Faculty, Ataturk University, Erzurum, Turkey; c: Bayburt University, Faculty of Arts and Design, Department of Interior Architecture and Environmental Design, Bayburt, Turkey; d: Golyaka Vocational and Technical Anatolian High School, Duzce, Turkey;

* Corresponding author: umitayata@bayburt.edu.tr

\section{INTRODUCTION}

Currently, several years after the use of wood heat treatment processes began, there are many well-established commercial processes, such as ThermoWood® (Finland), Plato Wood ${ }^{8}$ (Netherlands), OHT-Oil Heat Treatment wood (Germany), Retification (France), and Perdure (started in France but moved to Canada since a Canadian company (PCI industries) bought the patent). In the last decade, several new processes have emerged, some using vacuum to protect wood from oxygen, such as Termovuoto® (Allegretti et al. 2012), Moldrup-SSP $\AA$, and TanWood $\AA$; others using overheated steam by a closed autoclave system, such as ThermoTreat $2.0 ®$ or Firmolin ${ }^{\circledR}$; and others that apply minor changes to the original processes, such as Westwood ${ }^{\circledR}$. The changes in wood properties depend on the heat treatment method, but mostly they depend on temperature and time of treatment. The high temperatures used in thermal modification alter the chemical composition of the wood, producing a new material with improved properties (Esteves and Pereira 2009). The decrease in equilibrium moisture content is one of the main advantages of treated wood, which in turn increases dimensional stability. This increase has been attributed to the decreased accessibility by water molecules to hydroxyl groups in the wood, resulting from increased crystallinity of cellulose and increased cross-linking in 
lignin (Boonstra and Tjeerdsma 2006; Esteves et al. 2006, 2007). The treatment also improves wood durability by increasing resistance to fungi, except when in contact with soil, and slightly increases resistance to insects, though it has little effect on termite resistance (Nunes et al. 2004; Hakkou et al. 2006; Surini et al. 2012; Ayata et al. 2017). Wood also becomes darker in color, with less gloss (Aksoy et al. 2011; Esteves et al. 2019), less wettability (Hakkou et al. 2005), and lower thermal conductivity (Şahin Kol and Sefil 2011). The weakest part of heat treatment is the degradation of most of the mechanical properties, such as impact, static bending strength, and stiffness (Poncsák et al. 2006); compression strength (Korkut et al. 2008); and tensile strength (Boonstra et al. 2007). Most of the mechanical properties seem to increase in the beginning of the treatment or during low temperature treatments, and subsequently decrease (Kubojima et al. 2000; Boonstra et al. 2007).

Heat treatment is generally applied to low-value species to enable their utilization in harsher environments. In the last few years, however, heat treatment has been used to non-chemically change wood color of more valuable species, mainly in flooring applications. This affects wood properties including hardness, which is one of wood's most important properties, and critical for applications like flooring, decking, and stairs. Like to other mechanical properties, an initial increase in hardness has been reported by several authors (Tjeerdsma et al. 1998; Sivonen et al. 2002; Poncsák et al. 2006; Sundqvist et al. 2006; Korkut et al. 2008; Gurleyen et al. 2017). This initial increase has been attributed to condensation reactions in lignin and hemicellulose (Sundqvist et al. 2006).

In contrast, hardness decreases when wood is subjected to more severe treatments using higher temperatures or longer treatment times (Gunduz et al. 2009). The cited authors reported that surface hardness of heat-treated hornbeam treated at $210{ }^{\circ} \mathrm{C}$ for $12 \mathrm{~h}$ decreased $55 \%, 54 \%$, and $38 \%$ for tangential, radial, and longitudinal directions, respectively. The decrease was generally greater in tangential and radial directions than in the longitudinal direction. For instance, the Yildiz (2002) study of heat-treated wood at 180 ${ }^{\circ} \mathrm{C}$ for $10 \mathrm{~h}$ showed a decrease in beech of $41.8 \%, 45.1 \%$ and $25.9 \%$, and, in spruce, a decrease of $42.5 \%, 43.0 \%$, and $19.7 \%$, in tangential, radial, and longitudinal directions, respectively. Contrary results were reported by Korkut et al. (2008) for heat-treated Scots pine at $180{ }^{\circ} \mathrm{C}$ for $10 \mathrm{~h}$, which showed a $41 \%$ decrease in the longitudinal direction, $39 \%$ in the tangential direction, and $27 \%$ in the radial direction. In accordance to Salca and Hiziroglu (2014), who studied the effect of heat treatment at $120^{\circ} \mathrm{C}$ and $190{ }^{\circ} \mathrm{C}$ for $3 \mathrm{~h}$ and $6 \mathrm{~h}$ on the surface hardness of black alder (Alnus glutinosa L.), red oak (Quercus falcata Michx.), Southern pine (Pinus taeda L.), and yellow poplar (Liriodendron tulipifera), the changes in hardness depended on the species. They achieved a high decrease for red oak $(41.7 \%)$ and a lower decrease for black alder (7.9\%), but found no notable differences in Southern pine or yellow poplar for similar treatments. These differences were attributed to anatomical features such as porosity. Likewise, Shi et al. (2007) mentioned that hardness increased or decreased in accordance with species, directions (radial, tangential, and longitudinal), and type of treatment.

The decrease in hardness can be associated to the mass loss in the cell wall as well as to density, which has a similar behavior to hardness (Gunduz et al. 2009). For instance, in the Yildiz (2002) study that examined the heat treatment of beech and spruce woods, there was a minor density increase for beech $(2.25 \%)$ and spruce $(1.73 \%)$ woods that underwent treatments at $130{ }^{\circ} \mathrm{C}$ for $2 \mathrm{~h}$. For treatments at higher temperatures $\left(200{ }^{\circ} \mathrm{C}, 10\right.$ h), however, density decreased $18.37 \%$ and $10.53 \%$ for beech and spruce woods, respectively; hardness, too, decreased. 
Shore hardness, like most hardness methods, measures the resistance toward indentation of a material with the difference that can be done in situ. Similar tests were already made, for instance, for in-process properties estimation and monitoring of silicone rubbers (Zhao et al. 2015). Shore hardness in accordance with ASTM D2240 (2010) has 12 different scales and can determine the hardness of elastomers, rubbers, plastic, cellular materials, and gels. The most common scales are the Shore A for the softer materials and Shore D for harder ones. In wood and wood composites, Shore-D hardness is preferred (Karamanoglu and Akyildiz 2013; Mattos et al. 2015; Chu et al. 2016; Li et al. 2018). Shore hardness is already commonly used with several wood composites such as wood plastic composites (Vedrtnam et al. 2019; Bhaskar et al. 2020), pine sawdust mixed with polyvinyl alcohol adhesive ( $\mathrm{Li}$ et al. 2011), wood polymerized with montmorillonite (Wang et al. 2014), composites prepared by free radical in situ polymerization of methacrylate monomers into pinewood (Mattos et al. 2015), poplar wood impregnated with phenolic resins (Li et al. 2018), or rubber composites using wood flour has filling (Nitz et al. 2000; Kilınç et al. 2019). Uses with solid wood have been more scarce, but nevertheless there are some examples such as the tests made by Sahin and Onay (2020) for alternative wood species for playgrounds wood from fruit trees or a study on suitability of some wood species for landscape applications (Şahin et al. 2020). There have also been some studies with heat-treated wood such as the determination of hardness properties of heat-treated Anatolian black pine, Calabrian pine, sessile oak, and chestnut (Karamanoglu and Akyildiz 2013) or the determination of surface characteristics of poplar wood with high-temperature heat treatment (Chu et al. 2016).

This paper studied the Shore-D hardness (ASTM D2240 2010) of some wood species before and after heat treatment (ThermoWood method), and the effect that wood species and heat treatment had on the observed changes.

\section{EXPERIMENTAL}

Fourteen different species were used in this study in order to include the highest range possible from low density to high density species in accordance to the species that are commonly used and naturally more available for heat treatment in the Duzce region (Turkey). Density ranged from $0.367 \mathrm{~g} / \mathrm{cm}^{3}$ to $1.122 \mathrm{~g} / \mathrm{cm}^{3}$. Sipo (Entandrophragma utile), merbau (Intsia bijuga), afrormosia (Pericopsis elata), wenge (Millettia laurentii), sapelli (Entandrophragma cylindricum), teak (Tectona grandis L.), zebrano (Microberlinia brazzavillensis), doussié (Afzelia africana), Santos (Myroxylon balsamum), rose (Dalbergia nigra), Acajou d'Afrique (Khaya anthotheca), limba/fraké (Terminalia superba), duka (Tapirira guianensis), and tali (Erythrophleum suaveolens) species were obtained from the Duzce industrial zone in Duzce, Turkey. The samples were $100 \mathrm{~mm} \times$ $100 \mathrm{~mm} \times 10 \mathrm{~mm}$ (longitudinal $\times$ tangential $\times$ radial) and conditioned according to ISO 554 (1976). The samples were kept at $23 \pm 2{ }^{\circ} \mathrm{C}$ and $50 \pm 5 \%$ relative humidity until equilibrium was reached.

\section{Methods}

Heat treatment

All wood samples were heat-treated at $212{ }^{\circ} \mathrm{C}$ for $1 \mathrm{~h}$ and $2 \mathrm{~h}$, according to the ThermoWood method, in the Novawood Factory located in Gerede, Bolu, Turkey. After 
the treatment, the samples were reconditioned according to ISO $554(1976)$ at $23 \pm 2{ }^{\circ} \mathrm{C}$ and $50 \pm 5 \%$ relative humidity.

\section{Density determination}

Density was determined for wood conditioned at $23 \pm 2{ }^{\circ} \mathrm{C}$ and $50 \pm 5 \%$ relative humidity by measuring the sample dimensions with a caliper and weighing them in a scale.

\section{Determination of Shore-D hardness}

The Shore-D hardness measurements of all samples, untreated and heat-treated, were done according to the ASTM D2240 (2010) standard. Figure 1 shows the Shore-D hardness device (Shenzhen Omena Technology Co., Ltd., Guangdong, China). A 5-kg load was used as the weight to determine hardness.
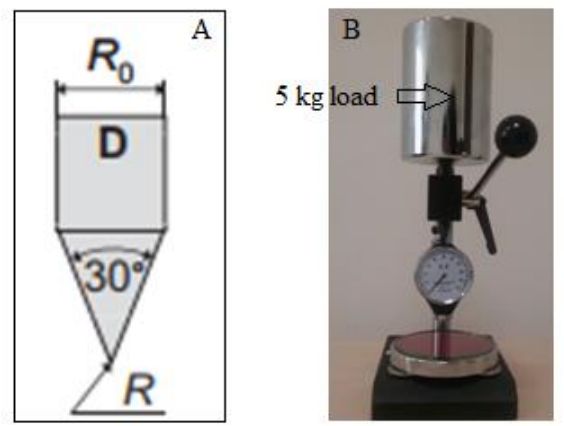

Fig. 1. Definition ( $0 \mathrm{~N} \leq \mathrm{F} \leq 44.5 \mathrm{~N}, 0 \mathrm{~mm} \leq \mathrm{h} \leq 2.5 \mathrm{~mm}$ ) (Grellmann and Seidler 2014) (A), and Shore-D hardness device (B)

The values of $R_{0}$ and $R$ depend on the scale used. For Shore-D hardness, $R_{0}=1.25$ $\mathrm{mm}$ and $R=0.1 \mathrm{~mm}$. The Shore-D scale goes from 0 to 100 , where 100 corresponds to having a $44.45 \mathrm{~N}$ spring force calibration.

\section{Statistical analysis}

The SPSS 17 (Sun Microsystems, Inc., Santa Clara, CA, USA) program was used to calculate the statistical analysis. Minimum, maximum, variation coefficients, homogeneity groups, standard deviations, and averages of the Shore-D hardness test results applied to heat-treated and untreated wood materials were determined. The analysis of variance (ANOVA) and Duncan tests were also performed.

\section{RESULTS AND DISCUSSION}

Table 1 presents the Shore-D hardness of all untreated and heat-treated wood for 1 $\mathrm{h}$ and $2 \mathrm{~h}$ at $212^{\circ} \mathrm{C}$ in accordance with the ThermoWood method. The Shore-D hardness of untreated wood ranged between 35.3 for Limba wood and 77.2 for Santos wood, giving Limba the lowest hardness and Santos the highest hardness of all studied materials. In Fig. 1 it can be seen that Limba wood exhibited much smaller hardness than the remaining woood species. The untreated wood hardness of this study was in the range of that presented by other authors with different species, such as Ayata (2020) with Ayous wood (Triplochiton scleroxylon) who obtained 37.6; Devi and Maji (2012) found a 40.0 ShoreD hardness for simul wood (Salmalia malabarica); Mattos et al. (2015) determined 42.6 
for loblolly pine (Pinus taeda), Hazarika and Maji (2013) determined 45.0 for fig (Ficus hispida); Yan et al. (2015) determined 46.4 for poplar (Populus tomentosa); Devi et al. (2003) determined 46.6 for rubber wood (Hevea brasiliensis); and Karamanoğlu and Kaymakçi (2018) determined 64.1 for chestnut (Castanea sativa).

With heat treatment, hardness decreased for all the species studied. The decrease was higher in samples with harsher treatment $\left(2 \mathrm{~h}\right.$ at $\left.212{ }^{\circ} \mathrm{C}\right)$. The decrease in hardness was higher for Sipo wood, falling from 68.4 to 58.6, which corresponded to a $14 \%$ decrease compared with the untreated wood. The lowest decrease was observed in Afrormosia, whose hardness decreased from 56.8 to 55.4, corresponding to a $2.5 \%$ reduction (Table 1 and Fig. 1). There seems to have been no relation between the degree of hardness decrease with heat treatment and the initial hardness of the wood samples, as can be seen in Fig. 1. Similar results in several species have been presented by different authors. For instance, Salca and Hiziroglu (2014) studied the heat treatment of four wood species, black alder (Alnus glutinosa L.), red oak (Quercus falcata Michx.), Southern pine (Pinus taeda L.), and yellow poplar (Liriodendron tulipifera), each treated at two temperatures, $120{ }^{\circ} \mathrm{C}$ and $190{ }^{\circ} \mathrm{C}$, for $3 \mathrm{~h}$ and $6 \mathrm{~h}$. These authors reported a hardness decrease that reached $41.7 \%$ for red oak when treated at $190{ }^{\circ} \mathrm{C}$ for $6 \mathrm{~h}$. Smaller decreases were found for black alder $(7.9 \%)$, and no notable differences were found between the treated and untreated samples of Southern pine and yellow poplar.

Results, however, have shown that hardness can increase when using less severe treatments, leading to a marked decrease for higher temperatures and treatment times. These results were reported by Karamanoglu and Akyildiz (2013) in Anatolian black pine (Pinus nigra), Calabrian pine (Pinus brutia), sessile oak (Quercus petraea), and chestnut (Castanea sativa), each treated at $130{ }^{\circ} \mathrm{C}, 180{ }^{\circ} \mathrm{C}$, and $230{ }^{\circ} \mathrm{C}$ temperatures $(2$ and $8 \mathrm{~h}$ ). The authors stated that although the hardness increased at $130{ }^{\circ} \mathrm{C}$ and $180{ }^{\circ} \mathrm{C}$, it decreased at $230{ }^{\circ} \mathrm{C}$. Analogous results were obtained in different studies, such as Akyildiz et al. (2009), who reported the heat treatment of Anatolian black pine wood at $130{ }^{\circ} \mathrm{C}, 180{ }^{\circ} \mathrm{C}$, and $230{ }^{\circ} \mathrm{C}$, and Ates et al. (2009) with Calabrian pine. Although their studies used the Janka method to determine hardness, both obtained a similar increase followed by a decrease. These results show that the use of higher temperatures might also have some impact in the decrease in hardness. Therefore, even with the same mass loss, higher temperature might lead to a higher decrease in hardness. Since in this study a temperature of $212^{\circ} \mathrm{C}$ was used, which is normally considered as a high temperature, that would explain why there was a decrease in hardness even with only $1 \mathrm{~h}$ hour treatment at $212{ }^{\circ} \mathrm{C}$. The type of hardness measurement might also have some impact in these results, since Shore$\mathrm{D}$ hardness is a measurement taken more superficially than other hardness measurements, and for heat-treated wood there might be some difference between hardness of the first layer of wood that is more exposed than the layers beneath. In accordance with Dumail et al. (1998), the shape of the indentation tool, the speed of loading, the depth of penetration and most likely how wood failure is induced during testing significantly affected hardness results.

The initial increase in hardness might be due to the increased crosslinking in lignin turning the material harder. The decrease in hardness for more severe treatments is probably due to the high mass loss that weakens the wood, and this effect is higher than the effect in lignin crosslinking. The mass loss starts with hemicelluloses that are known to have a significant influence on wood properties, and for more intense treatments the loss of hemicelluloses is significant. Similar conclusions were reported by Ates et al. (2009). 
Table 1. Shore-D Hardness and Density for Untreated and Heat-treated Wood

\begin{tabular}{|c|c|c|c|c|c|c|c|c|}
\hline Wood Type & $\begin{array}{c}\text { Heat } \\
\text { Treatment }\end{array}$ & Mean & $H G$ & $S D$ & \begin{tabular}{|l} 
Mini- \\
mum
\end{tabular} & \begin{tabular}{|l} 
Maxi- \\
mum
\end{tabular} & COV & $\begin{array}{l}\text { Density } \\
\left(\mathrm{g} / \mathrm{cm}^{3}\right)\end{array}$ \\
\hline \multirow{3}{*}{$\begin{array}{c}\text { Sipo } \\
\text { (Entandrophragma } \\
\text { utile) }\end{array}$} & Control & 68.40 & $E$ & 0.52 & 68.00 & 69.00 & 0.76 & 0.812 \\
\hline & $212^{\circ} \mathrm{C}$ for $1 \mathrm{~h}$ & 63.00 & $\mathrm{H}$ & 2.94 & 59.00 & 66.00 & \begin{tabular}{|l|}
4.67 \\
\end{tabular} & 0.791 \\
\hline & $212^{\circ} \mathrm{C}$ for $2 \mathrm{~h}$ & 58.60 & $\mathrm{NO}$ & 1.71 & 57.00 & 61.00 & 2.92 & 0.673 \\
\hline \multirow{3}{*}{$\begin{array}{c}\text { Tali } \\
\text { (Erythrophleum } \\
\text { suaveolens) }\end{array}$} & Control & 68.50 & $E$ & 1.18 & 66.00 & 70.00 & 1.72 & 0.912 \\
\hline & $212^{\circ} \mathrm{C}$ for $1 \mathrm{~h}$ & 65.60 & $\mathrm{~F}$ & 0.52 & 65.00 & 66.00 & 0.79 & 0.875 \\
\hline & $212^{\circ} \mathrm{C}$ for $2 \mathrm{~h}$ & 65.40 & $\mathrm{~F}$ & 0.52 & 65.00 & 66.00 & 0.80 & 0.838 \\
\hline \multirow{3}{*}{$\begin{array}{c}\text { Santos } \\
\text { (Myroxylon } \\
\text { balsamum) }\end{array}$} & Control & 77.20 & $A^{*}$ & 1.23 & 75.00 & 78.00 & 1.59 & 1.122 \\
\hline & $212^{\circ} \mathrm{C}$ for $1 \mathrm{~h}$ & 73.60 & $\mathrm{~B}$ & 0.52 & 73.00 & 74.00 & 0.71 & 0.925 \\
\hline & $212^{\circ} \mathrm{C}$ for $2 \mathrm{~h}$ & 70.90 & D & 1.10 & 68.00 & 72.00 & 1.55 & 0.837 \\
\hline \multirow{3}{*}{$\begin{array}{c}\text { Rose } \\
\text { (Dalbergia } \\
\text { nigra) }\end{array}$} & Control & 76.80 & A & 1.93 & 75.00 & 79.00 & 2.51 & 1.023 \\
\hline & $212^{\circ} \mathrm{C}$ for $1 \mathrm{~h}$ & 73.20 & $\mathrm{BC}$ & 0.79 & 72.00 & 74.00 & 1.08 & 0.913 \\
\hline & $212^{\circ} \mathrm{C}$ for $2 \mathrm{~h}$ & 72.40 & C & 0.70 & 71.00 & 73.00 & 0.97 & 0.908 \\
\hline \multirow{3}{*}{$\begin{array}{c}\text { Zebrano } \\
\text { (Microberlinia } \\
\text { brazzavillensis) }\end{array}$} & Control & 64.20 & $G$ & 0.79 & 63.00 & 65.00 & 1.23 & 0.792 \\
\hline & $212^{\circ} \mathrm{C}$ for $1 \mathrm{~h}$ & 60.20 & $\mathrm{KL}$ & 0.92 & 59.00 & 61.00 & 1.53 & 0.785 \\
\hline & $212^{\circ} \mathrm{C}$ for $2 \mathrm{~h}$ & 60.10 & KLM & 0.57 & 59.00 & 61.00 & 0.95 & 0.752 \\
\hline \multirow{3}{*}{$\begin{array}{c}\text { Teak } \\
\text { (Tectona } \\
\text { grandis L.) } \\
\end{array}$} & Control & 59.10 & LMN & 0.74 & 58.00 & 60.00 & 1.25 & 0.641 \\
\hline & $212^{\circ} \mathrm{C}$ for $1 \mathrm{~h}$ & 52.90 & $\mathrm{~S}$ & 0.99 & 52.00 & 55.00 & 1.87 & 0.459 \\
\hline & $212^{\circ} \mathrm{C}$ for $2 \mathrm{~h}$ & 51.00 & $T$ & 0.67 & 50.00 & 52.00 & 1.31 & 0.408 \\
\hline \multirow{3}{*}{$\begin{array}{l}\text { Afrormosia } \\
\text { (Pericopsis } \\
\text { elata) }\end{array}$} & Control & 56.80 & $P Q$ & 0.79 & 56.00 & 58.00 & 1.39 & 0.663 \\
\hline & $212^{\circ} \mathrm{C}$ for $1 \mathrm{~h}$ & 56.20 & QR & 0.63 & 56.00 & 58.00 & 1.12 & 0.603 \\
\hline & $212^{\circ} \mathrm{C}$ for $2 \mathrm{~h}$ & 55.40 & $\mathrm{R}$ & 0.52 & 55.00 & 56.00 & 0.94 & 0.584 \\
\hline \multirow{3}{*}{$\begin{array}{c}\text { Sapelli } \\
\text { (Entandrophragma } \\
\text { cylindricum) }\end{array}$} & Control & 61.80 & 1 & 1.32 & 60.00 & 63.00 & 2.14 & 0.745 \\
\hline & $212^{\circ} \mathrm{C}$ for $1 \mathrm{~h}$ & 60.30 & JKL & 0.48 & 60.00 & 61.00 & 0.80 & 0.596 \\
\hline & $212^{\circ} \mathrm{C}$ for $2 \mathrm{~h}$ & 57.70 & OP & 0.82 & 57.00 & 59.00 & 1.42 & 0.568 \\
\hline \multirow{3}{*}{$\begin{array}{l}\text { Doussié } \\
\text { (Afzelia } \\
\text { africana) }\end{array}$} & Control & 64.70 & $F G$ & 2.45 & 61.00 & 67.00 & 3.79 & 0.672 \\
\hline & $212^{\circ} \mathrm{C}$ for $1 \mathrm{~h}$ & 59.10 & LMN & 1.20 & 58.00 & 61.00 & 2.03 & 0.645 \\
\hline & $212^{\circ} \mathrm{C}$ for $2 \mathrm{~h}$ & 57.00 & $P Q$ & 1.76 & 54.00 & 59.00 & 3.09 & 0.633 \\
\hline \multirow{3}{*}{$\begin{array}{c}\text { Acajou } \\
\text { d'Afrique } \\
\text { (Khaya anthotheca) } \\
\end{array}$} & Control & 56.20 & QR & 0.79 & 55.00 & 57.00 & 1.41 & 0.570 \\
\hline & $212^{\circ} \mathrm{C}$ for $1 \mathrm{~h}$ & 52.20 & $\mathrm{~S}$ & 0.79 & 51.00 & 53.00 & 1.51 & 0.555 \\
\hline & $212^{\circ} \mathrm{C}$ for $2 \mathrm{~h}$ & 50.10 & $\mathrm{~T}$ & 1.29 & 49.00 & 52.00 & 2.57 & 0.424 \\
\hline \multirow{3}{*}{$\begin{array}{c}\text { Duka } \\
\text { (Tapirira } \\
\text { guianensis) }\end{array}$} & Control & 60.40 & JK & 1.84 & 58.00 & 63.00 & 3.05 & 0.665 \\
\hline & $212^{\circ} \mathrm{C}$ for $1 \mathrm{~h}$ & 58.90 & $\mathrm{MN}$ & 1.20 & 58.00 & 61.00 & 2.04 & 0.627 \\
\hline & $212^{\circ} \mathrm{C}$ for $2 \mathrm{~h}$ & 58.90 & $\mathrm{MN}$ & 0.74 & 58.00 & 60.00 & 1.26 & 0.604 \\
\hline \multirow{3}{*}{$\begin{array}{l}\text { Wenge } \\
\text { (Millettia } \\
\text { laurentii) }\end{array}$} & Control & 63.90 & $\mathrm{GH}$ & 1.79 & 62.00 & 68.00 & 2.80 & 0.692 \\
\hline & $212^{\circ} \mathrm{C}$ for $1 \mathrm{~h}$ & 59.60 & KLMN & 1.51 & 58.00 & 61.00 & 2.53 & 0.675 \\
\hline & $212^{\circ} \mathrm{C}$ for $2 \mathrm{~h}$ & 57.20 & $P Q$ & 0.92 & 55.00 & 58.00 & 1.61 & 0.663 \\
\hline \multirow{3}{*}{$\begin{array}{l}\text { Limba/Fraké } \\
\text { (Terminalia } \\
\text { superba) }\end{array}$} & Control & 35.30 & $U$ & 0.48 & 35.00 & 36.00 & 1.36 & 0.367 \\
\hline & $212^{\circ} \mathrm{C}$ for $1 \mathrm{~h}$ & 33.30 & $\mathrm{~V}$ & 0.48 & 33.00 & 34.00 & 1.44 & 0.353 \\
\hline & $212^{\circ} \mathrm{C}$ for $2 \mathrm{~h}$ & 32.20 & $W^{* *}$ & 1.03 & 31.00 & 33.00 & 3.20 & 0.317 \\
\hline \multirow{3}{*}{$\begin{array}{l}\text { Merbau } \\
\text { (Intsia } \\
\text { bijuga) }\end{array}$} & Control & 65.80 & $\mathrm{~F}$ & 2.04 & 63.00 & 68.00 & 3.10 & 0.830 \\
\hline & $212^{\circ} \mathrm{C}$ for $1 \mathrm{~h}$ & 61.40 & IJ & 0.84 & 61.00 & 63.00 & 1.37 & 0.801 \\
\hline & $212^{\circ} \mathrm{C}$ for $2 \mathrm{~h}$ & 59.20 & KLMN & 1.03 & 58.00 & 61.00 & 1.74 & 0.783 \\
\hline
\end{tabular}

Fig. 1. Hardness variation for the tested untreated and heat-treated woods

In accordance with Mania et al. (2020), the most commonly accepted function describing the relation between density and hardness is the power function $\left(H=\rho^{n}\right)$, with $n$ ranging from 1.1 to 2.25 . Nevertheless, different functions were reported to describe the relation between density and hardness. 


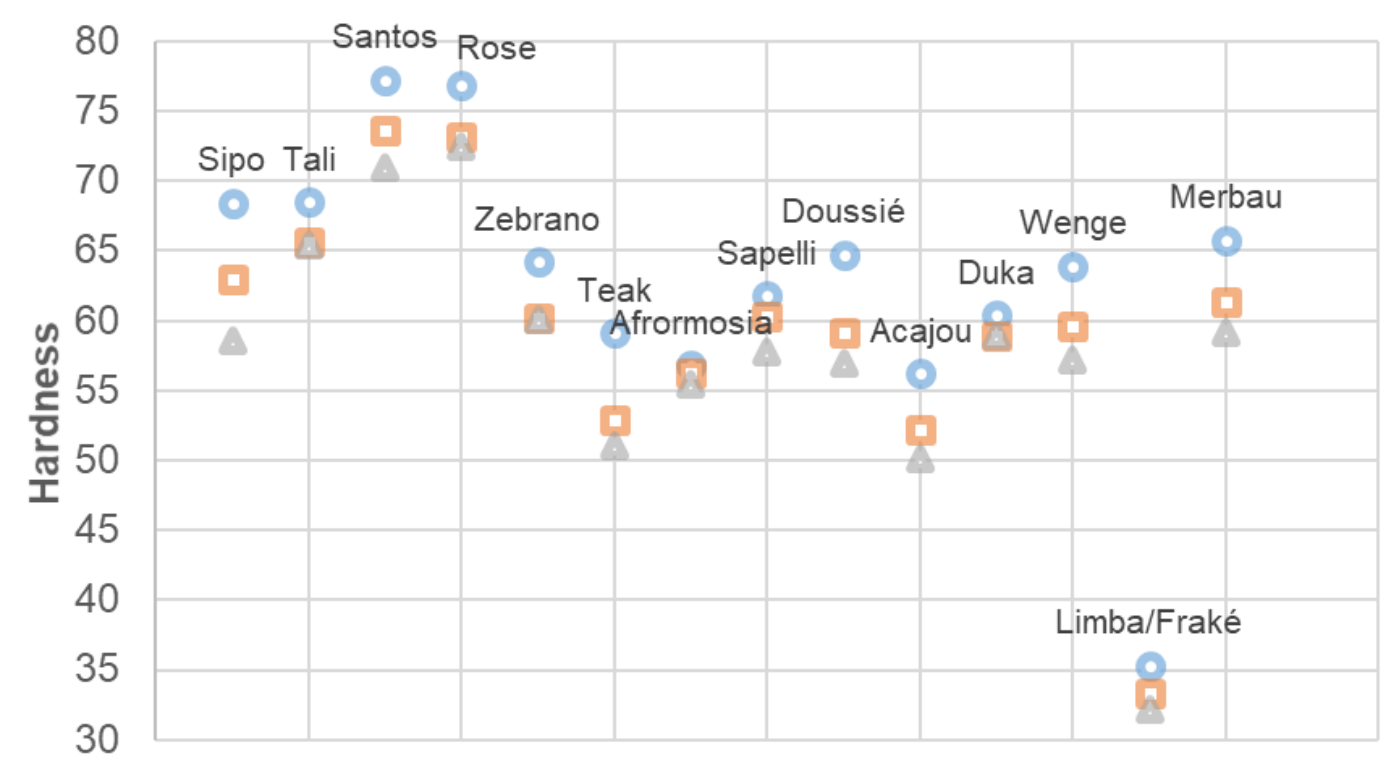

Initial $\square 1 \mathrm{~h} \triangle 2 \mathrm{~h}$

Fig. 1. Hardness variation for the tested untreated and heat-treated woods

Figure 2 presents the relation between Shore-D hardness and wood density. Additionally, Table 2 presents the best regressions obtained between hardness and density. The linear model using all of the samples obtained an $\mathrm{R}^{2}$ of 0.854 , which improved slightly to 0.876 when using only untreated wood. Gunduz et al. (2009) found linear relations between density and hardness of heat-treated hornbeam wood. Similar results were reported by Peng et al. (2016), who studied the influence of density and equilibrium moisture content on the hardness anisotropy of wood for three softwoods, Chinese fir, red pine, Mongolian scotch pine, and three hardwoods, Manchurian walnut, Asian white birch, and Mongolian oak. These authors reported different linear correlations for radial $\left(\mathrm{R}^{2}=\right.$ $\left.0.72 ; R^{2}=0.88\right)$, tangential $\left(R^{2}=0.44 ; R^{2}=0.77\right)$, and cross sections $\left(R^{2}=0.33 ; R^{2}=0.88\right)$ for softwoods and hardwoods, respectively. Since in this study the measurement was made in tangential section, the obtained $\mathrm{R}^{2}$ were higher than the obtained by Peng et al. (2016). Dumail et al. (1998) reported $\mathrm{R}^{2}$ ranging from 0.53 to 0.88 for the relation between density and hardness of juvenile maritime pine wood. These authors also cited an earlier work made by Ylinen (1943) where a linear correlation was also obtained.

The potential model obtained better $\mathrm{R}^{2}$ ranging from 0.860 for all samples to 0.909 for untreated samples. Similar results but with lower determination coefficients were reported before. Damayanti et al. (2020) reported several potential models relating density and hardness of young fast grown plantation teak with $\mathrm{R}^{2}$ ranging from 0.51 for radial section to 0.53 for tangential section.

Nevertheless, the model that gave the best results was the exponential model with $\mathrm{R}^{2}$ of 0.906 for all samples and 0.944 . This model is presented in Fig. 2, and it seems to fit well the results.

Heat treatment seems to reduce the quality of the fittings since all the determination coefficients for heat treated wood alone were lower than the ones for untreated wood (Table 
2 ), which is probably due to the chemical changes in wood due to heat treatment that transform wood into an altered material with different properties.

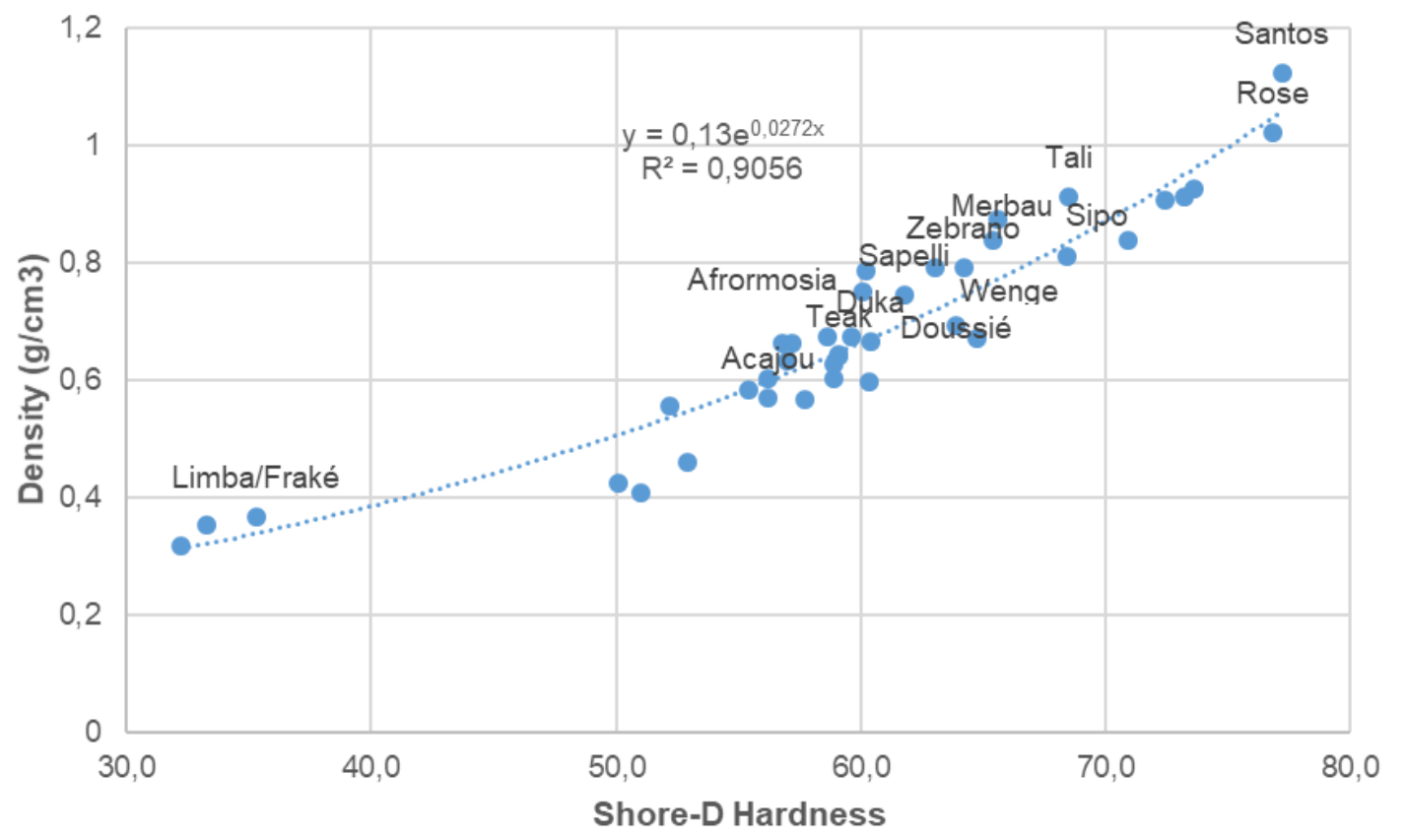

Fig. 2. Relation between Shore-D hardness and wood density

Table 2. Linear, Potential, and Exponential Regression Analysis for Untreated and Heat-treated Wood Alone or Together

\begin{tabular}{|c|c|c|c|}
\hline Regression analysis & Untreated & Heat-treated & All \\
\cline { 2 - 4 } Linear & $\mathrm{y}=0.0174 \mathrm{x}-0.3443$ & $\mathrm{y}=0.0163 \mathrm{x}-0.2881$ & $\mathrm{y}=0.0168 \mathrm{x}-0.3159$ \\
\cline { 2 - 4 } & $\mathrm{R}^{2}=0.8758$ & $\mathrm{R}^{2}=0.8307$ & $\mathrm{R}^{2}=0.8542$ \\
\cline { 2 - 4 } Potential & $\mathrm{y}=0.0024 \mathrm{x}^{1.3807}$ & $\mathrm{y}=0.0023 \mathrm{x}^{1.3869}$ & $\mathrm{y}=0.0022 \mathrm{x}^{1.3977}$ \\
\cline { 2 - 4 } & $\mathrm{R}^{2}=0.909$ & $\mathrm{R}^{2}=0.8321$ & $\mathrm{R}^{2}=0.8602$ \\
\hline \multirow{2}{*}{ Exponential } & $\mathrm{y}=0.1417 \mathrm{e}^{0.026 \mathrm{x}}$ & $\mathrm{y}=0.1261 \mathrm{e}^{0.0276 x}$ & $\mathrm{y}=0.13 \mathrm{e}^{0.0272 x}$ \\
\cline { 2 - 4 } & $\mathrm{R}^{2}=0.9442$ & $\mathrm{R}^{2}=0.8832$ & $\mathrm{R}^{2}=0.9056$ \\
\hline
\end{tabular}

A two-way ANOVA test was performed to understand whether the Shore-D hardness was significantly different between wood species and varied heat treatments. The results are shown in Table 2. According to ANOVA tests, there was a significant difference between wood species at the chosen level of significance $(\mathrm{P} \leq 0.05)$. This difference can also be seen in Table 1 in the homogeneity groups where only Sipo, Tali, Santos, and Rose untreated wood belonged to the same groups, meaning that their Shore-D hardness was statistically similar. Parallel behavior was seen in treated wood. ANOVA tests also showed that there was a significant difference between various heat treatments, as discussed before. The interaction (Table 3) was also considered significant at the level $\mathrm{P} \leq 0.05$, showing that the effect of heat treatment on hardness varied with wood species. In accordance with Salca and Hiziroglu (2014), the statistical analysis showed that hardness of the samples was mostly influenced by the heat temperature and the cumulative effect of treatment temperature and wood species. 
Table 3. Variance Analysis Results for Shore-D Hardness Test Determined in Wood Species Before and After Heat Treatment

\begin{tabular}{|c|c|c|c|c|c|}
\hline Sources & $\begin{array}{c}\text { Sum of } \\
\text { Squares }\end{array}$ & $\begin{array}{c}\text { Degrees of } \\
\text { Freedom }\end{array}$ & $\begin{array}{c}\text { Mean } \\
\text { Square }\end{array}$ & $\begin{array}{c}\mathrm{F} \\
\text { Value }\end{array}$ & $\begin{array}{c}\text { Level of } \\
\text { Significance }\end{array}$ \\
\hline Wood Species (A) & 37463.212 & 13 & 2881.786 & 1953.928 & $0.000^{*}$ \\
\hline Heat Treatment (B) & 1984.933 & 2 & 992.467 & 672.919 & $0.000^{*}$ \\
\hline Interaction (AB) & 460.667 & 26 & 17.718 & 12.013 & $0.000^{*}$ \\
\hline Error & 557.500 & 378 & 1.475 & & \\
\hline Total & 1546113.000 & 420 & & & \\
\hline \multicolumn{7}{|c}{ *: Significant (P $\leq 0.05)$} \\
\hline
\end{tabular}

The results of the Shore-D hardness test singly carried out comparisons for each wood type and heat treatment and are given in Table 4. Again, these results clearly showed that there was a decrease in hardness of the tested wood species with the heat treatment.

Shore-D hardness is an efficient method to compare wood hardness. A main advantage of this method is that Shore hardness can be measured directly in a production line or in small wood companies without using a universal test machine. The knowledge of this hardness might help decision makers choose the right wood for each application.

Table 4. Results of Singly Carried Out Comparisons for Each Wood Type and Heat Treatment

\begin{tabular}{|c|c|c|c|}
\hline Wood Type & Number of Measurements & Mean & HG \\
\hline Limba/Fraké (Terminalia superba) & 30 & 33.60 & $\mathrm{~K}^{\star *}$ \\
\hline Acajou d Afrique (Khaya anthotheca) & 30 & 52.83 & $\mathrm{~J}$ \\
\hline Teak (Tectona grandis L.) & 30 & 54.33 & $\mathrm{I}$ \\
\hline Afrormosia (Pericopsis elata) & 30 & 56.13 & $\mathrm{H}$ \\
\hline Duka (Tapirira guianensis) & 30 & 59.40 & $\mathrm{G}$ \\
\hline Sapelli (Entandrophragma cylindricum) & 30 & 59.93 & $\mathrm{FG}$ \\
\hline Wenge (Millettia laurentii) & 30 & 60.23 & $\mathrm{~F}$ \\
\hline Doussié (Afzelia africana) & 30 & 60.27 & $\mathrm{~F}$ \\
\hline Zebrano (Microberlinia brazzavillensis) & 30 & 61.50 & $\mathrm{E}$ \\
\hline Merbau (Intsia bijuga) & 30 & 62.13 & $\mathrm{D}$ \\
\hline Sipo (Entandrophragma utile) & 30 & 63.33 & $\mathrm{C}$ \\
\hline Tali (Erythrophleum suaveolens) & 30 & 66.50 & $\mathrm{~B}$ \\
\hline Santos (Myroxylon balsamum) & 30 & 73.90 & $\mathrm{~A}$ \\
\hline Rose (Dalbergia nigra) & 30 & 74.13 & $\mathrm{~A}^{*}$ \\
\hline Heat Treatment & Number of Measurements & Mean & $\mathrm{HG}$ \\
\hline Control (Untreated) & 140 & 62.79 & $\mathrm{~A}^{*}$ \\
\hline $212^{\circ} \mathrm{C}$ for $1 \mathrm{~h}$ & 140 & 59.25 & $\mathrm{~B}$ \\
\hline $212^{\circ}$ C for $2 \mathrm{~h}$ & 140 & 57.58 & $\mathrm{C}^{* *}$ \\
\hline HG: Homogeneity Group, ${ }^{*}$ : Highest Value, ${ }^{* *}$ : Lowest Value & \\
\hline
\end{tabular}

\section{CONCLUSIONS}

1. The Shore-D hardness of untreated wood ranged between 35.3 for Limba wood and 77.2 for Santos wood representing a wide range of hardness.

2. With heat treatment, hardness decreased for all the species studied, and the decrease was greater in samples with harsher treatment $\left(2 \mathrm{~h}\right.$ at $\left.212^{\circ} \mathrm{C}\right)$. The decrease in hardness was greater for Sipo wood (14\%) and lowest for Afrormosia wood (2.5\%). There seems 
to be no relation between the degree of hardness decrease with heat treatment and the initial hardness of wood.

3. A close relation was found between density and Shore-D hardness. Hardness was higher for higher densities. The exponential model gave the best results followed by the potential model and the linear one.

4. ANOVA tests showed that there was a significant difference between wood species, heat treatment, and interaction between both variables at the chosen level of significance $(\mathrm{P} \leq 0.05)$.

\section{ACKNOWLEDGMENTS}

The authors would like to thank Novawood Factory, Gerede, in Bolu, Turkey, for heat treating according to ThermoWood. This work was financed by national funds through FCT - Fundação para a Ciência e Tecnologia, I.P., under the project UIDB/00681/2020. Furthermore, the authors would like to thank the Instituto Politécnico de Viseu and CERNAS for their support.

\section{REFERENCES CITED}

Aksoy, A., Deveci, M., Baysal, E., and Toker, H. (2011). "Colour and gloss changes of Scots pine after heat modification," Wood Research 56(3), 329-336.

Akyildiz, M. H., Ates, S., and Özdemir, H. (2009). "Technological and chemical properties of heat-treated Anatolian black pine wood," African Journal of Biotechnology 8(11), 2565-2572. DOI: 10.5897/AJB09.306

Allegretti, O., Brunetti, M., Cuccui, I., Ferrari, S., Nocetti, M., and Terziev, N. (2012). "Thermo-vacuum modification of spruce (Picea abies Karst.) and fir (Abies alba Mill.) wood," BioResources 7(3), 3656-3669.

ASTM D2240 (2010). "Standard test method for rubber property - Durometer hardness," ASTM International, West Conshohocken, PA, USA.

Ates, S., Akyildiz, M. H., and Ozdemir, H. (2009). "Effects of heat treatment on Calabrian pine (Pinus brutia Ten.) wood," BioResources 4(3), 1032-1043.

Ayata, U. (2020). "Determination of some technological properties in Ayous wood and its color and glossiness properties after heat-treatment," Furniture and Wooden Material Research Journal 3(1), 22-33. DOI: 10.33725/mamad.724596

Ayata, U., Akcay, C., and Esteves, B. (2017). "Determination of decay resistance against Pleurotus ostreatus and Coniophora puteana fungus of heat-treated scotch pine, oak and beech wood species," Maderas. Ciencia y Tecnologia 19(3), 309-316. DOI: 10.4067/S0718-221X2017005000026

Bhaskar, K., Jayabalakrishnan, D., Kumar, M. V., Sendilvelan, S., and Prabhahar, M. (2020). "Analysis on mechanical properties of wood plastic composite," Materials Today: Proceedings, Elsevier. DOI: 10/ghpf8r

Boonstra, M. J., and Tjeerdsma, B. (2006). "Chemical analysis of heat-treated softwoods," Holz als Roh- und Werkstoff 64(3), 204-211. DOI: 10.1007/s00107-0050078-4 
Boonstra, M. J., Van Acker, J., Tjeerdsma, B. F., and Kegel, E. V. (2007). "Strength properties of thermally modified softwoods and its relation to polymeric structural wood constituents," Annals of Forest Science 64(7), 679-690. DOI: 10.1051/forest:2007048

Chu, D., Xue, L., Zhang, Y., Kang, L., and Mu, J. (2016). "Surface characteristics of poplar wood with high-temperature heat treatment: Wettability and surface brittleness," BioResources 11(3), 6948-6967. DOI: 10.15376/biores.11.3.6948-6967

Damayanti, R., Dewi, L. M., Ozarska, B., Illic, J., and Pari, G. (2020). “Assessing ultrastructure and density properties to predict wood hardness of young fast grown plantation teak," in: IOP Conference Series: Materials Science and Engineering, IOP Publishing, 012026. DOI: 10/ghqdpw

Devi, R. R., Ali, I., and Maji, T. K. (2003). "Chemical modification of rubber wood with styrene in combination with a crosslinker: Effect on dimensional stability and strength property," Bioresource Technology 88(3), 185-188. DOI: 10.1016/S09608524(03)00003-8

Devi, R. R., and Maji, T. K. (2012). "Study on properties of simul wood (Bombax ceiba L.) impregnated with styrene acrylonitrile copolymer, $\mathrm{TiO}_{2}$, and nanoclay," Polymer Bulletin 69, 105-123. DOI: 10.1007/s00289-012-0742-x

Dumail, J.-F., Castéra, P., and Morlier, P. (1998). "Hardness and basic density variation in the juvenile wood of maritime pine," in: Annales des Sciences Forestières, EDP Sciences, 911-923.

Esteves, B. M., and Pereira, H. M. (2009). "Wood modification by heat treatment: A review," BioResources 4(1), 370-404. DOI: 10.15376/biores.4.1.370-404

Esteves, B., Ayata, U., and Gurleyen, L. (2019). "Effect of heat treatment on the colour and glossiness of black locust, wild pear, linden, alder and willow wood," Drewno 62(203), 39-52. DOI: 10.12841/wood.1644-3985.267.10

Esteves, B., Domingos, I., and Pereira, H. (2007). "Improvement of technological quality of eucalypt wood by heat treatment in air at 170-200 degrees C," Forest Products Journal 57(1), 47-52.

Esteves, B., Marques, A. V., Domingos, I., and Pereira, H. (2006). "Influence of steam heating on the properties of pine (Pinus pinaster) and eucalypt (Eucalyptus globulus) wood," Wood Science and Technology 41(3), 193-207. DOI: 10.1007/s00226-0060099-0

Grellmann, W., and Seidler, S. (2014). Part 3: Mechanical and Thermomechanical Properties of Polymers: Subvolume A: Polymer Solids and Polymer Melts, K.-F. Arndt and M. D. Lechner (eds.), Springer-Verlag, Berlin, Germany.

Gunduz, G., Korkut, S., Aydemir, D., and Bekar, Í. (2009). "The density, compression strength and surface hardness of heat treated hornbeam (Carpinus betulus L.) wood," Maderas. Ciencia y Tecnología 11(1), 61-70. DOI: 10.4067/S0718221X2009000100005

Gurleyen, L., Ayata, U., Esteves, B., and Cakicier, N. (2017). "Effects of heat treatment on the adhesion strength, pendulum hardness, surface roughness, color and glossiness of Scots pine laminated parquet with two different types of UV varnish application," Maderas. Ciencia y Tecnología 19(2), 213-224. DOI: 10.4067/S0718221X2017005000019

Hakkou, M., Pétrissans, M., El Bakali, I., Gérardin, P., and Zoulalian, A. (2005). "Wettability changes and mass loss during heat treatment of wood," Holzforschung 59(1), 35-37. DOI: 10.1515/HF.2005.006 
Hakkou, M., Pétrissans, M., Gérardin, P., and Zoulalian, A. (2006). "Investigations of the reasons for fungal durability of heat-treated beech wood," Polymer Degradation and Stability 91(2), 393-397. DOI: 10.1016/J.POLYMDEGRADSTAB.2005.04.042

Hazarika, A., and Maji, T. (2013). "Effect of different crosslinkers on properties of melamine formaldehyde-furfuryl alcohol copolymer/montmorillonite impregnated softwood (Ficus hispida)," Polymer Engineering and Science 53(7), 1394-1404. DOI: 10.1002/pen.23391

ISO 554 (1976). "Standard atmospheres for conditioning and/or testing-Specifications," International Organization for Standardization, Geneva, Switzerland.

Karamanoğlu, M., and Akyildiz, M. H. (2013). "Colour, gloss and hardness properties of heat-treated wood exposed to accelerated weathering," Pro Ligno 9(4), 729-738.

Karamanoğlu, M., and Kaymakçi, A. (2018). "Effect of hygrothermal aging on color and hardness properties of heat-treated chestnut wood," Furniture and Wooden Material Research Journal 1(1), 31-37. DOI: 10.33725/mamad.429726

Kilınç, K., Kanbur, Y., and Tayfun, Ü. (2019). "Mechanical, thermo-mechanical and water uptake performance of wood flour filled polyurethane elastomer ecocomposites: influence of surface treatment of wood flour," Holzforschung 73(4), 401407. DOI: 10/ghpf7z

Korkut, S., Akgül, M., and Dündar, T. (2008). "The effects of heat treatment on some technological properties of Scots pine (Pinus sylvestris L.) wood,"Bioresource Technology 99(6), 1861-1868. DOI: 10.1016/j.biortech.2007.03.038

Kubojima, Y., Okano, T., and Ohta, M. (2000). "Bending strength and toughness of heattreated wood," Journal of Wood Science 46(1), 8-15. DOI: 10.1007/BF00779547

Li, G. C., Chen, J., Li, Q., and Yang, T. (2011). "Biodegradable composites from pinewood sawdust and polyvinyl alcohol adhesives," in: Advanced Materials Research, Trans Tech Publ, 59-63.

Li, J., Zhang, A., Zhang, S., Gao, Q., Chen, H., Zhang, W., and Li, J. (2018). "Highperformance imitation precious wood from low-cost poplar wood via high-rate permeability of phenolic resins," Polymer Composites 39(7), 2431-2440. DOI: $10.1002 /$ pc. 24226

Mania, P., Wróblewski, M., Wójciak, A., Roszyk, E., and Moliński, W. (2020). "Hardness of densified wood in relation to changed chemical composition," Forests, 11(5), 506. DOI: 10/ghqcp6

Mattos, B. D., de Cademartori, P. H. G., Missio, A. L., Gatto, D. A., and Magalhães, W. L. E. (2015). "Wood-polymer composites prepared by free radical in situ polymerization of methacrylate monomers into fast-growing pinewood," Wood Science and Technology 49(6), 1281-1294. DOI: 10.1007/s00226-015-0761-5

Nitz, H., Reichert, P., Römling, H., and Mülhaupt, R. (2000). "Influence of compatibilizers on the surface hardness, water uptake and the mechanical properties of poly (propylene) wood flour composites prepared by reactive extrusion," Macromolecular Materials and Engineering 276(1), 51-58. DOI: 10/fpdrj3

Nunes, L., Nobre, T., and Rapp, A. O. (2004). Thermally Modified Wood in Choice Tests with Subterranean Termites, COST E37, Reinbeck, IA, USA.

Peng, H., Jiang, J., Zhan, T., and Lu, J. (2016). "Influence of density and equilibrium moisture content on the hardness anisotropy of wood," Forest Products Journal, 66(7-8), 443-452. DOI: 10.13073/FPJ-D-15-00072 
Poncsák, S., Kocaefe, D., Bouazara, M., and Pichette, A. (2006). "Effect of high temperature treatment on the mechanical properties of birch (Betula papyrifera)," Wood Science and Technology 40, 647-663. DOI: 10.1007/s00226-006-0082-9

Şahin Kol, H., and Sefil, Y. (2011). "The thermal conductivity of fir and beech wood heat treated at 170, 180, 190, 200, and 212 C," Journal of Applied Polymer Science 121(4), 2473-2480. DOI: 10.1002/app.33885

Sahin, C. K., and Onay, B. (2020). "Alternative wood species for playgrounds wood from fruit trees," Wood Research 65(1), 149-160. DOI: 10/ghpf8q

Şahin, C. K., Topay, M., and Var, A. A. (2020). "A study on suitability of some wood species for landscape applications: surface color, hardness and roughness changes at outdoor conditions," Wood Research 65(3), 395-404. DOI: 10/ghpf77

Salca, E.-A., and Hiziroglu, S. (2014). "Evaluation of hardness and surface quality of different wood species as function of heat treatment," Materials \& Design 62, 416423. DOI: 10.1016/j.matdes.2014.05.029

Shi, J. L., Kocaefe, D., and Zhang, J. (2007). "Mechanical behaviour of Québec wood species heat-treated using ThermoWood process," Holz als Roh- und Werkstoff 65(4), 255-259. DOI: 10.1007/s00107-007-0173-9

Sivonen, H., Maunu, S. L., Sundholm, F., Jämsä, S., and Viitaniemi, P. (2002). "Magnetic resonance studies of thermally modified wood," Holzforschung 56(6), 648-654. DOI: 10.1515/HF.2002.098

Sundqvist, B., Karlsson, O., and Westermark, U. (2006). "Determination of formic-acid and acetic acid concentrations formed during hydrothermal treatment of birch wood and its relation to colour, strength and hardness," Wood Science and Technology 40(7), 549-561. DOI: 10.1007/s00226-006-0071-z

Surini, T., Charrier, F., Malvestio, J., Charrier, B., Moubarik, A., Castéra, P., and Grelier, S. (2012). "Physical properties and termite durability of maritime pine Pinus pinaster Ait., heat-treated under vacuum pressure," Wood Science and Technology 46(1-3), 487-501. DOI: 10.1007/s00226-011-0421-3

Tjeerdsma, B. F., Boonstra, M., Pizzi, A., Tekely, P., and Militz, H. (1998). "Characterisation of thermally modified wood: Molecular reasons for wood performance improvement," Holz als Roh- und Werkstoff 56(3), 149-153. DOI: $10.1007 / \mathrm{s} 001070050287$

Vedrtnam, A., Kumar, S., and Chaturvedi, S. (2019). "Experimental study on mechanical behavior, biodegradability, and resistance to natural weathering and ultraviolet radiation of wood-plastic composites," Composites Part B: Engineering, Elsevier, 176, 107282. DOI: 10/ghpf75

Wang, W., Zhu, Y., Cao, J., and Liu, R. (2014). "Improvement of dimensional stability of wood by in situ synthesis of organo-montmorillonite: Preparation and properties of modified Southern pine wood," Holzforschung 68(1), 29-36. DOI: 10/gbfnp4

Yan, Y., Dong, Y., Li, J., Zhang, S., Xia, C., Shi, S. Q., and Cai, L. (2015). "Enhancement of mechanical and thermal properties of poplar through the treatment of glyoxal-urea/nano-SiO $2, " R S C$ Advances 5(67), 54148-54155. DOI: 10.1039/C5RA07294H

Yildiz, S. (2002). Physical, Mechanical, Technological and Chemical Properties of Beech and Spruce Wood Treated by Heating, Master's Thesis, Karadeniz Technical University, Trabzon, Turkey.

Ylinen, A. (1943). "Über den Einfluß der Rohwichte und des Spätholzanteils auf die Brinellhärte des Holzes," Holz als Roh-und Werkstoff 6(4), 125-127. DOI: 10/csw8gh 
Zhao, H., Allanson, D., and Ren, X. J. (2015). "Use of shore hardness tests for in-process properties estimation/monitoring of silicone rubbers," Journal of Materials Science and Chemical Engineering 3(07), 142-147. DOI: 10/ghpf78

Article submitted: October 19, 2020; Peer review completed: December 5, 2020; Revised version received and accepted: December 23, 2020; Published: January 8, 2021.

DOI: 10.15376/biores.16.1.1482-1495 